\title{
Chuma Ulete: Business and Discourses of Witchcraft in Neoliberal Tanzania
}

\section{Jacqueline H. Mgumia jhm11@albion.edu}

\author{
'Lest I change your name and call you Chuma Ulete' \\ (Mwakyusa 2017)
}

\begin{abstract}
The private business sector has been expanding rapidly in urban Tanzania since the country started liberalizing its economy in the 1980s. Witchcraft discourses linked to the business sector have emerged side by side with the increased liberalization of public spaces and media. Drawing from an ethnographic study of 52 adolescents with small businesses in urban Dar es Salaam, Tanzania, and a Foucauldian analysis of popular discourses on witchcraft and business, I attempt here to make sense of why witchcraft is invoked in a sector that is conventionally viewed as the realm of economic rationality in neoliberal discourses. In this article, I suggest that capital, knowledge, and markets, which continue to be presented as necessary conditions for business growth, are not sufficient in explaining why certain businesses fail and others succeed. It rather suggests context specific reasons that may explain how adolescents with small businesses end up embracing popular discourses that link business success or failure to witchcraft, such as Chuma Ulete (reap and bring). It also explains the impact that such an embrace has on the ways in which these young people with small businesses are engaging with entrepreneurship. This entails unpacking how witchcraft ends up being invoked by those who need their businesses to grow as well as explaining how they take pre-emptive measures to protect their businesses from such apparent witchcraft.
\end{abstract}

Keywords: Witchcraft, business, entrepreneurship, youth, adolescent, Tanzania, neoliberalism 


\section{Introduction}

In January 2013 I embarked on a two-year PhD fieldwork for an ethnographic study to observe 52 young aspiring entrepreneurs taking part in a project that involved the starting of small and medium businesses through a grant of TSh200,000 (Tanzanian Shillings; approximately US\$150 at the time) from the Norwegian School of Economics $(\mathrm{NHH})^{1}$. The grant was a practical mechanism used by the project to test if the adolescents who had received business training from the University of Dar es Salaam Entrepreneurship Centre (UDEC), in partnership with $\mathrm{NHH}$, were more likely to utilize the business grant productively than those who were not given the said training. Two months later, after 41 of these 52 youths had started their businesses, I met with them to discuss their initial experiences of running businesses as well as to assess the extent to which their access to the business grant and entrepreneurship training impacted their start-up process. Contrary to my expectations, where I expected discussions about the challenges of the business environment and customer or policy regulations, they suggested the practice of using witchcraft, particularly dawa (medicine) in small businesses to attract customers and/or protect their businesses from failure. Although, in its literal translation from Kiswahili, the term 'dawa' means 'medicine', in such witchcraft discourses it is invoked to refer to the usage of charms or amulets in businesses.

The adolescents pointed out that, in doing business, they have heard that some successful businesspeople in their localities used dawa to ensure business success. Others pointed out that in small businesses there are incidences of magical theft known as chuma ulete (reap and bring), which can lead to people making a profit in their small businesses while their rivals make a loss or stagnate. Since the focus-group discussions in the original study were designed to assess which business principles and practices from the entrepreneurship training were useful in the start-up process and utilization of the business grant, I asked the youths not to dwell on the issue of witchcraft. The reason was that I did not originally think that witchcraft could have any relevance to the assessment of rational reasons on why there

According to the Ministry of Trade and Industry (2012:10), it was estimated that the average start-up investment for a small business was TSh220,500, with an investment of up to TSh2,000,000 being estimated to qualify being a mediumscale investment. 
would be success or failure in the start-up process and utilization of the business grant.

However, a week later, when I was helping one of the adolescents to carry merchandise to her stall, she rhetorically asked how a business could grow in their street while everybody else was sitting around. While I was in the process of digesting the question posed, she added, 'My mother said she has never seen anything grown in this street as there are too many witches!' (Mgumia 2017:102). A month later, when I was hanging out in another adolescent's shop, I observed the owner refusing to take a note of TSh5,000 from a customer who wanted to buy a cigarette, claiming that it was magic money, which could siphon her sales of the day in mysterious way. Of course, she did not say that to the customer, rather she gave the cigarette to the customer on credit, asking the customer to bring the TSh200 later, as she did not have change. I knew she had change as I saw her counting her money that morning. When I asked why she did not take the money and lied to the customer, she argued that the customer was a witch with magic money that could make her sales disappear if she took it and put it in her money drawer. How she knew that the customer was a witch and that the money had magical power was a mystery to me. It was at this point when I became more aware of the ubiquity of discourses of witchcraft in business and decided to observe it more closely in the future.

From 2017 to 2019 I undertook a secondary postdoctoral research project with the aim to critically explain how discourses of witchcraft interact with discourses of business, alongside other popular discourses of gender, religious worship, and humor, to shape the everyday lives of young Tanzanians aspiring to make money as entrepreneurs. This secondary study applied the same ethnographic data gathering techniques, including observation, focus-group discussions, and photography, on the same group of young entrepreneurs in urban Dar es Salaam who participated in the fieldwork for my doctoral study (Mgumia 2017). I also complemented the study with the additional use of discourse analysis techniques, including the content analysis of the social media, advertisements from traditional healers, and experts on dawa in Tanzania, as well as a critical discourse analysis of the 
lyrics of a popular song, entitled Chuma Ulete (Mgumia 2020 [forthcoming] $)^{2}$.

In analyzing the results of the application of ethnographic techniques and the content analysis of primary data from a variety of media, my conception of witchcraft distinguished between individuals who were characterized as witches and those who were called traditional healers. Both groups have one characteristic in common, which is the dispensing of medicine (dawa). Witches are said to use dawa to cause harm to others, while healers are said to use dawa to help the sick to get better or help those undertaking a particular task to succeed in what they happen to be doing (Lewis 1997; Mesaki 1995; Singleton 1979). Contextual factors provided cues as to the interpretation that the term 'dawa' would receive. In business, witchcraft discourses determine the preferred interpretation of dawa, with some businesspeople being said to be successful because they have good dawa for success while their fellow businesspeople whose businesses are proving unsuccessful are said to have bad dawa thrown at them by their rivals or witches who want to exploit their profits.

The discourse on witchcraft in business among adolescents in my doctoral study and later in the postdoctoral study tended to posit a definition of witchcraft that viewed it as a term used, in Swahili, to refer to wachawi (witches) or waganga wa kienyeji (traditional healers) - both of whom were viewed as wataalam (traditional experts of witchcraft) with a special trained/ inherited expertise in making dawa (medicine) that was believed to have the capacity to harm or protect a business. It is pertinent to observe that in everyday discourses, the context of language being used determines whether the given language user wishes the mtaalam (expert) in dispensing dawa (medicine, especially in the form of charms or amulets) to be viewed as a mganga (traditional healer) or mchawi (witch). Depending on the perspective encouraged by the user of the terms in a given context, witchcraft is thus associated with an accumulation of wealth as much as it is associated with a decline in one's prosperity (Sanders 1999; Lindhardt 2009).

In this article, therefore, I attempt to make sense of why witchcraft is invoked in a sector that is conventionally viewed as the realm of economic

2 That article mainly focuses on popular discourses of chuma ulete in the social media in Tanzania, whereas this article primarily focuses on the discourses of chuma ulete among adolescent businesspeople. 
rationality in neoliberal discourses. By this I mean discourses - i.e. practices and ideas - advanced in the contexts of neoliberalism, which is both an ideology and an economic system centered on the retreat of the state through liberalization, marketization, and privatization (Chachage \& Mbilinyi 2003; Shivji 2006). My interest in particularly drawing attention to the local concept and practice of chuma ulete is to unpack how discourses of witchcraft interact with discourses of business, alongside other popular discourses of gender, religious affiliation, and humor, to shape the everyday lives of young Tanzanians aspiring to make money as entrepreneurs. It would thus seem that discourses of witchcraft permeate social and market relations (Gaskill 2010).

In these contexts, capital, knowledge, and the market that continue to be presented as the necessary conditions for business growth in entrepreneurship training, are not sufficient in explaining why a certain business fails or succeeds. One needs to unpack how popular discourses of witchcraft, such as chuma ulete, impact the way that businesspeople engage with their businesses. This entails unpacking how witchcraft is invoked to make a business grow and how one protects one's business from it. Using the case of young entrepreneurs, I thus argue that, as a popular discourse of witchcraft, chuma ulete is used as prevention, diagnosis, and treatment predicated on marginal gains in small businesses. As such, some adolescents draw on chuma ulete to make sense of their business practices and to control their business outcomes. The ubiquitous popular discourses of witchcraft transcend beliefs because even young people who do not seem to subscribe to conclusions based on its social grip on account of their religious or scientific affiliations, do nevertheless also acknowledge its influence on business success or failure. I use discourses in a Foucauldian sense to imply that these are sets of ideas and practices that do not only shape or inform the objects and/or subjects that it refers to, but also interact with related or varying discourses in doing so ${ }^{3}$.

Three sections constitute the article. The first section briefly revisits the literature on entrepreneurship to underscore the silences on witchcraft in business studies and training. The second section refers to discourses of magical theft, magical money, and business medicine in various locales in Africa that are not explicitly presented as the rationality to explain marginal gains in small businesses. From this, I conceptualize chuma ulete as 'witch-

3 Adapted from Foucault $(1972 ; 1979 ; 1982)$ and Senellart and Foucault (2008). 
craft for the poor' on the basis of its apparent agency and locality. What follows is an analytical presentation of the ethnography of chuma ulete by using the case of three youths in my study on young entrepreneurship and their business start-ups.

\section{Silences about Witchcraft in Business Studies}

Literature on the interface between a belief in witchcraft and the pursuit of individual wealth accumulation in neoliberal economies suggests that the increase of inequalities and skewed access to business opportunities tend to occasion an increase in witchcraft accusations, rumors, and practices among businesspeople in marketplaces, communities, and media (Sanders 2001; Green \& Mesaki 2005; Sherrington 2007; Lindhardt 2009) ${ }^{4}$. A dependent neoliberal economy seems to be characterized by much economic turbulence and uncertainty that result in the petty bourgeois participants in small- and medium-scale business enterprises to put their trust in seemingly irrational forces, like betting and miraculous happenings. This kind of economic context prompts the emergence of a mindset of uncertainty among these types of small-scale traders that tends to be easily persuaded by beliefs in the occult and magic. At the same time, there has been a significant growth of advertisement of wataalam in public spaces that offer business medicine for protection and prosperity of businesses (Lindhardt 2009). As a result, everyday conversations carry numerous accounts of how profits and losses in businesses are linked with practices of witchcraft.

In both the print and social media, a number of businesspeople is reported using money, time, and energy in attempting to control their business outcomes through the application of witchcraft. With respect to religion, there is an established followership on what is termed the 'Gospel of Prosperity', which is believed to have powers to create and protect wealth (Lindhardt 2009:41).

In the field of art, it is worth noticing that Tanzania has witnessed an increase in artistic products from 2010 to 2019 in terms of songs and movies, which carry varieties of themes about witchcraft and wealth. With regard to movies, it is pertinent to observe that, even though witchcraft in Tanzania has

4 These are some of the leading scholars and researchers of witchcraft in and on Tanzania. 
existed for centuries, Tanzanian movies on witchcraft only started being produced in the 2000s. This can partly be explained by the influence of Nigerian movies on witchcraft. Therefore, it is plausible to assume that, since Nigerian movies are widely watched in Tanzania, some influence from Nigeria on the witchcraft discourses in Tanzanian movies may have taken place. However, the experience of witchcraft and business is not a mythical issue confined to cinematic scenes; it is rather a common theme in public discussions.

In their everyday conversations, people use words such as 'witches' and 'business medicine' in humorous conversations that are meant to question the basis of the material success of others. Some conversations portray physical harm to thieves who steal from businesspeople who may be protected by witchcraft or dawa provided by healers. Recently, the social media in Tanzania has shown various alleged thieves being reported to be made to suffer as a consequence of measures taken against them due to having stolen from supposedly witchcraft protected businesses ${ }^{5}$.

Yet, witchcraft is not explicitly or implicitly conceptualized or problematized as an issue in the business world. For instance, in the threemonth training on entrepreneurship and business start-up offered by UDEC to adolescents in my doctoral research study, referred to earlier, witchcraft was not considered as a factor to reckon with in the success of the project. Given the extent to which witchcraft occupies a dominant position in popular business success and failure discourses in Tanzania, I was surprised as to why it was not given some due weight as an important contextual factor in

5 One video shows a person at a police station with a sack of maize that is supposed to have 'refused' to be laid on the ground for more than eight hours after having been stolen from a shop. This person is reported to have surrendered himself to the police station seeking for help in 'forcing' the sack of maize 'to agree' to be laid to the ground. Unfortunately, the police are reported to have failed to persuade the sack of maize to agree to be laid on the ground and the alleged thief was advised to return the sack of maize to the shop of the owner where the thief had originally stolen it from (African Gospel 2017). Another YouTube video that is no longer available online, shows a man in the Tanga region who has decided to return a stolen phone handset to its owner after his hand that had stolen the phone allegedly got surrounded by bees for a couple of days. Similar videos from the neighboring countries, Kenya and Uganda, have been posted online (cf. K24 TV 2018; Mohab TV online 2018). 
explaining success and failure in business. It may be presumed that, since UDEC courses on entrepreneurship are of an academic character like many other courses on entrepreneurship and business, the training focuses on familiarizing trainees with the more official, rational, scientific discourses of the economy. The training does not acknowledge the need to familiarize the trainees with the seemingly irrational occult or witchcraft discourses of the economy or other spiritual aspects of human endeavors.

The neglect of witchcraft as an important contextual factor in the success or failure of businesses in Africa may have resulted from the general tendency among scholars of entrepreneurship to problematize witchcraft as a conservative force that resists change, development, and modernity - a perspective that seems to be outdated among scholars who study witchcraft. As such, business losses or successes are hardly likely to be explained in terms of witchcraft, as that would be regarded as an indicator of backwardness. In this article, however, I take the considered view that, although beliefs in witchcraft do tend to appear as irrational to those who do not believe in its existence - hence the use of the term 'superstition' in various 'modernist' discourses - it has its own rationality, according to the anthropological literature on witchcraft in Africa (Mesaki 1993; Geschiere 1997; Comaroff \& Comaroff 1999).

The silence on witchcraft in studies on businesses is also caused by the nature of the disciplines that have dealt with the subject. Most of the writings about witchcraft are confined to the disciplines of Anthropology, History, and Religion. However, in his seminal work on The modernity of witchcraft, Geschiere (1997) suggests that it is difficult to find sufficient evidence to support the foundation of rigid boundaries between what constitutes tradition and what represents modernity, especially noting how witchcraft shapes the everyday lives of some communities, for example, in this case, the Cameroonians. He then calls for Anthropology to study local concepts and practices of occult forces to liberate itself from moralizing witchcraft. Ashforth (2005) also makes a profound argument that the future of democracy in South Africa will depend on how the government will take seriously the spiritual insecurity caused by witchcraft. In Reconsidering witchcraft, Sanders (2003:338) argues, with particular reference to Tanzania, that witchcraft may also be about other phenomena that are ordinarily taken to be rational. In this sense, I argue that businesses are one of those phenomena that amplify discourses of witchcraft. 


\section{Witchcraft for the Poor}

In Tanzania, like in many parts of Africa, the use of witchcraft to accumulate wealth is a well-documented terrain in Anthropology. As pointed out earlier, popular witchcraft discourses make a distinction between witchcraft which is viewed negatively, and spiritual healing which is viewed positively. This is akin to what one may argue, in rational terms, that fantasy ought to be distinguished from reality or blind faith, and trust from evidence-based propositions (Gaskill 2010:94-95). Indeed, the neoliberal economic turbulence and uncertainties would seem to occasion a demand for the services of both Abrahamic faith (i.e. Christian and Muslim) and traditional African healers to boost the morale of businesspeople in continuing with business undertakings even in hard times (Lindhardt 2016:153, 157). The demand for a rational inspirational support to undertake a business is invariably open and upfront for aspiring entrepreneurs, while the temptation for them to use witchcraft to increase their prospects for business growth tends to be cloaked in secrecy and shrouded in rumormongering about its potency.

Literature on the subject suggests that witchcraft presents a means for some Africans to participate or deal with the mystery of global commerce (Geschiere 2006), manifesting differently, depending on the context and location (Bongmba 2001; Crick 1976). Some of these manifestations are accounts of the accumulation of material wealth through occult forces in Tanzania (Sanders 2001; Lindhardt 2012) and other parts of Africa (Meyer 1995). However, with this article, I want to highlight a form of witchcraft that focuses on leaking or stealing wealth, known as chuma ulete, which has been popular in Tanzania since the 1990s. Although it has received little attention in the anthropological literature, it is popular in public discourses (Mgumia 2020 [forthcoming]). Thus, chuma ulete is perceived as the witchcraft for the poor, in contrast to the wealthy, as it is generally used to steal money from and/or for small businesses. In Tanzania, it is not strange to hear that business losses in small scale are associated with practices of chuma ulete. I therefore argue that this form of witchcraft provides a possibility for providing an explanation for some instances of marginal gains in the market economy for some participants in witchcraft discourses.

However, it is important to point out that wealth loss through witchcraft is not a new concept in anthropological literature. Early anthropologists, such as Evans-Pritchard (1937), Gluckman (1944), and Fortes (1953), 
define witchcraft as a coherent ideology to clarify unexplainable misfortunes as it answers the question on why a given misfortune has occurred to a particular person at a particular point in time and place. It is seen as a frame of knowledge, framing the causation of good and bad of societies. If someone is facing a misfortune of wealth loss, there has to be someone who caused it such suspicions are confirmed through traditional rituals. After such a diagnosis, treatment in the form of protection, and justice in terms of punishment are provided accordingly.

Following the challenges of globalization, modernity, and capitalism, witchcraft is also used both as a 'social diagnostics rather than belief' (Moore \& Sanders 2001:4) and as a means to accumulate power and wealth to participate in the global economy (Geschiere 2006; Meyer 1995; Green \& Mesaki 2005). It may indeed be argued that even this use of witchcraft as a social diagnostic instrument is not totally new, since it was also used in traditional African settings involving the pursuit of individual wealth, much as this previously was to a very limited extent (Horton 1967). Nevertheless, the use of witchcraft as a social diagnostic instrument has indeed taken center stage with its use not only as a means, but also as an avenue for providing explanations for dealing and living with processes and inequalities of modernization and globalization in a neoliberal economy that marginalizes the majority (Sanders 2003; Richter, Flowers \& Bongmba 2017). This use is not only confined to scholars of witchcraft, but also to wataalam, and may also extend to people on the ground who attempt to speculate about the cause and effect (i.e. diagnosis) of seemingly unexplainable wealth and losses.

This suggests that some aspects of witchcraft beliefs (explanations of misfortune) go back a long time whereas other aspects of witchcraft beliefs, such as that of chuma ulete, are more recent and more related to the neoliberal globalization. It would appear that globalization has increasingly made the business life of small- and medium-sized enterprises more precarious and uncertain while creating a lot of expectations of success that are more based on fantasy than reality. As such, the aspect of witchcraft beliefs as an explanation for fortunes has also increasingly ascended.

Moreover, the questions of who participates in witchcraft and what types of witchcraft are used to accumulate wealth have been core to Anthropology. For instance, Evans-Pritchard (1937:426) notes the difference between noblemen and commoners in practicing witchcraft, whereby the former practices it with limitations as they believe that superstitious beliefs 
are more practiced by the latter due to envy and jealousy about wealth. In contemporary Tanzania, and in Africa in general, such distinction still holds to some extent with the wealth of the rich being more associated with the alleged witchcraft rituals of exclusive fraternities, such as Freemasonry and that of the poor with affordable dawa. Recent writings, however, indicate that witchcraft transcends economic, social, political, and related categories (Geschiere 1997; Ashforth 2005).

Powerful businesspeople and politicians are accused of using witchcraft to illegally gain power and wealth. Such wealth is concomitant with ritual killings, selling human body parts, cannibalism, and the usage of zombies to attain wealth. In Cameroon, for instance, Ekong witchcraft allows the accumulation of wealth associated with modernity - such as houses, cars, money, and modern equipment - through the exploitation of zombies who work in invisible plantations (Geschiere 2006:139). In Malawi, zombies are reported to live in the houses of businesspeople as security guards, wealth charms, or laborers (Englund 1996). In Asante, Ghana, businesspeople are said to use satanic powers to be connected to sika ntafowayi (magic money) by offering their relatives as sacrifices (McCaskie 2008:63; Meyer 1995:240241). In Tanzania, as Mesaki (1993) notes, there is a widespread belief that witches turn dead people into zombies to work for the benefit of the witch. In Iringa, a region in Tanzania, zombies are said to be used to work in shops and market stalls to attract customers and steal money from customers and business rivals (Lindhardt 2009:47). Similarly, businesspeople from Ihanzu in Tanzania use Kisumba, a dawa, to attract wealth and customers to their businesses while others use Ndag $\bar{u}$, a ritual sacrifice, for getting wealth (Sanders 2001:170-171).

It is also important to note that a witch is believed to have the capacity to accumulate one's wealth as well as to destroy one's wealth. As a result, in popular witchcraft discourses, it is not surprising that participants in these discourses who have benefited least from the exaggerated expectations for individual wealth accumulation that neoliberal economics promises, would tend to categorize the use of witchcraft as bad, while those who have benefited most tend to categorize it as good. This is particularly evident in the polarized Tanzanian social media between supporters and defenders of chuma ulete (Mgumia 2020 [forthcoming]).

Ihanzu witches, like many other witches in the world, are assumed to have 'two personal traits', namely 'greed and jealousy' (Sanders 1999:122). 
Generally, greed allows for wealth creation while jealousy destroys the wealth of others. In Tanzania, bad witches are predominantly poor witches who feel envy and are thus presumed to possess the most destructive witchcraft. Green and Mesaki (2005:373) also point out that 'discourses on witchcraft in Tanzania consistently address themes of envy, greed, consumption, cannibalism, and death'. Englund (1996:272) captures this demarcation in regard to witchcraft in Malawi:

The variations occur, in brief, within the parameters of envy, greed and protection. Envy (nsanje or dumbo) is said to motivate those witches who are 'poor' (osauka); the rich (olemera) are the usual targets of their witchcraft. Greed (Umbombo), by contrast, causes the 'rich' to afflict the 'poor' in their pursuit of wealth and prosperity (original emphasis).

Overall it may be argued that both the poor and envious, as well as the greedy and rich witches would all invariably be treated in popular witchcraft discourses as being bad. However, the bottom line in a neoliberal economic and social order is that success in private wealth creation invariably receives positive feedback, while dominant themes in the discourse present those who have become successful as the ones whose witchcraft is categorized as admirable and therefore good. Sanders (1999:122) also captures such a connection in the case of Tanzania: 'Thus, the most economical way for the witch to ensure maximum ruinous results - that is, to satisfy his [sic.] accumulative and destructive desire simultaneously - is by plundering the wealth by others. What witch gains, others loose'. At its worst, this is a situation akin to a zero-sum game. As I shall elaborate in the next section, chuma ulete occurs in such a paradigm where wealth is not generated but plundered.

Another important notion is the idea that the capacity of witchcraft for destruction and accumulation goes hand in hand with its capacity for protection. There is also a significant body of literature on wealth protection in Africa. For instance, in explaining the increase in witch-finding in Ghana, Olsen (2002:522) argues that anti-witchcraft sentiments were on the increase because of uneven economic growth and material successes in the context of Ghana's linkage to the global market. However, since most of the wealth is associated with occult forces, successful businesspeople and those who got 
money by magic means had to obtain what Olsen terms 'occult insurance': 'Businessmen or women who seriously considered their investments and riches', Olsen (2002:534) notes, 'also purchased the powers and assistance of witch-finding shrines in protecting their assets and property'. Similarly, Sanders (2001:169) observes that the 'common knowledge in Tanzania' is that 'people of wealth and power use business medicine to accumulate their wealth and protect it'. As such, the invocation of the term 'chuma ulete', bodes well with this dual purpose of witchcraft.

In connection with the power of witchcraft to destroy wealth, the magical disappearance of wealth is also a prominent topic in the literature. For instance, Meyer (1995:238) points out that when we hear about occult forces - actively or passively - there are people who become victims of evil powers, 'which manifest themselves through financial loss, sickness and marriage problems'. In providing testimonies of such loss, Meyer further notes that 'young aristocrats believed anti-witch shrines could provide people with bad character magical medicine to outwit them financially' (Meyer 1995:122). In Tanzania, witches have also traditionally been accused of stealing grains from their fellow villagers' farms. Such witchcraft in some of the areas is known as Makota - a dawa that pulls grains from other villages' farmers to a witch (Sanders 1990:122). This accusation is commonly leveled against people who farm on small plots that yield a big harvest in rural areas.

However, writing about kinship and witchcraft among Wayao street vendors in postsocialist urban Dar es Salaam, Malefakis (2018:67) looks at witchcraft accusations as a way of sustaining group morality rather than an effect of modernity in line with the views of Evans-Pritchard (1978). In this sense, the discourses of chuma ulete in the post-Nyerere neoliberal economy could also be seen as enforcing the morality of egalitarianism and care for the poor and elderly of the community, inherited from the socialist period of Ujamaa (familyhood), since, out of fear, they may get some things for free as it was generally the case prior to neoliberalization. Whereas witchcraft accusations have existed prior to neoliberalism, the ones associated with businesses have increasingly become visible in its wake as entrepreneurship became one the solutions to poverty.

As other researchers have also observed with respect to postcolonial (i.e. postapartheid) South Africa, there is a marked increase in witchcraftrelated wealth creation and anti-witchcraft sentiments and rumors that invariably take the form of witch-hunts that result in breaches of public order 
(Niehaus, Mohala \& Shokane 2001; Kohnert 2002). A similar grim situation occurs with regard to a marked increase in the use of witchcraft to enrich oneself. In the works by Bryceson, Jønsson, and Sherrington (2010) as well as Green and Mesaki (2005), there is also a marked increase in antiwitchcraft sentiments as a backlash against the experiences of the victims who are also witnesses to the abuses of the use of witchcraft in wealth creation. The socio-economic turbulence that continues to accompany changes in the political and economic spheres all over the world - changes that are occasioning tremendous institutional upheavals, resulting in the institution of many neoliberal reforms - would seem to foster a heightened engagement with a belief in the occult and the mystical on the part of large sections of citizens in dependent neoliberal economies. In line with this, Green (2015) observes that "witchcraft is not, despite systematic condemnnation by the governments seeking to prohibit it, a traditional and static social institution. It is a continually evolving assemblage'. As such, it is also modern.

From this perspective, one is forced to agree with Green (2015) that the 'study of witchcraft is inherently entangled with development as ideology', not least in light of the memorable remark attributed to the then President Ronald Reagan of the USA in an opening address at the 1983 annual meeting of the World Bank, that

the societies that achieved the most spectacular, broad-based economic progress in the shortest period of time have not been the biggest in size, nor the richest in resources and certainly not the most rigidly controlled. What has united them all was their belief in the magic of the marketplace. Millions of individuals making their own decisions in the marketplace will always allocate resources better than any centralized government planning process. Trust the people, this is the crucial lesson of history. Because only when the human spirit is allowed to worship, invent, create, and produce, only when individuals are given a personal stake in deciding their destiny and benefiting from their own risks - only then do societies become dynamic, prosperous, progressive and free (Reagan 1983:2; emphasis added).

Although this speech does not refer to magic in its strict superstitious sense, this remark by President Reagan was viewed as the political launch of the 
seemingly 'magical' neoliberal era in the early 1980s whereby individuals who were assumed to be great risk takers were said to be rewarded by accumulation of wealth beyond what was rationally possible for many. No wonder, even in the dependent neoliberal economies such as those in Tanzania, wealth accumulation was associated with being ready to take risks, as in gambling, and miraculously coming upon wealth in a way that leaves the other unlucky ones, the less adept at risk taking, with a tingle of jealousy that might tempt them to go and see a witchdoctor.

Thus, the concept of Geschiere (2006:60) relating to 'witchcraft of wealth' becomes useful in the context of small businesses in Tanzania, albeit when one looks at it dialectically in relation to what I refer to as 'witchcraft for the poor'. By this I mean the dialectics of wealth and poverty in the sense that the two are co-constituted. Key to witchcraft for wealth is the accumulation of wealth through magical means that involves invisible labor and kinship relations in connection to global processes. Witchcraft for the poor, on the other hand, is centered on envy toward the relatively successful businesspeople in the context of poverty. Slightly different from 'destructive witchcraft' (Msafiri 2008:88) or what Sanders (1999:122) refers to as destructive desires of witches that destroy people's wealth and the productive capacity of the producer, chuma ulete is what I dub 'parasitic witchcraft' that predominantly occurs in terms of 'witchcraft for the poor'. In such a case the meager wealth is not necessarily destroyed, while productive capacity is primarily maintained for the sake of siphoning money. It thus exists in the production process whereby the witch and the bewitched encounter each other as they both seek to alleviate poverty. Such a relation of production in a capitalist economy provides a distinctive discourse of witchcraft that moves away from the centrality of kinship relations in witchcraft to the relations of the seller and the buyer in the marketplace. This is particularly heightened in the neoliberal era that privileges marketized relations over classical capitalist social relations of production. As such, young entrepreneurs are drawing on embedded sets of beliefs in regard to witchcraft, which have been adapted to explain or even justify each new turn in the economic life of a businessperson. 


\section{Young Entrepreneurs and Chuma Ulete}

The 52 adolescents who participated in my study believed that there is an association between witchcraft and business. However, only six said that they have observed or witnessed someone being bewitched, while another six stated that they have experienced witchcraft in their lives. Interestingly, four of these related that they experienced it for the first time after they have started their businesses, while the remaining two said that they have experienced it before and not in relation to starting a business. Nevertheless, these experiences also affected their businesses and participation in the study. Making sense of how such encounters and accounts relate to different outcomes in investments enables one to understand why young entrepreneurs make and justify some choices about business locations, markets, and strategies. In this section, I am revisiting their encounters with, and accounts of chuma ulete, and attempt to contextualize it in relation to other popular discourses.

One morning as I was helping one of the adolescents to open her shop, an old man entered to buy a cigarette. He handed her a TSh500 note. After greeting him politely, the adolescent said that she did not have change. Pleadingly, he claimed that the other shops were closed and he really needed to smoke. The adolescent decided to give him the cigarette without taking the money, saying, 'Just take it' (Mgumia 2017:102). However, he insisted that she takes the money, saying that he will return for the change later. She refused to take it, claiming that not charging him was in fact a blessing to the beginning of her business day. The old man left with his note. This account resonates with the discussions on social media that single out elderly people who look poor as prime suspects of chuma ulete (Mgumia 2020 [forthcoming]).

On another occasion I visited an adolescent's business and discovered that he was extremely upset and unsettled. He claimed that he had mysteriously lost TSh220,000. The night before my arrival, he recalled earning TSh310,000 from selling meat. However, that morning he only had TSh80,000. I asked him to empty and check his pockets and bags thoroughly. We went through everything. Nothing more was found. I tried to help him to recall if he had lent it or given his bag to someone or if there was a possibility that the money had been stolen or dropped somewhere. Still confident about his earlier narrative, the young man provided the following detailed 
explanation: 'My cow had more than 200 kilos. I sold each kilo for TSh4,000. Only 100 kilos were bought on credit. The other 100 kilos were bought in cash by two buyers, each buying 50 kilos, making a total of TSh400,000'. He further recalled that he used $\mathrm{TSh} 70,000$ to pay a debt to a fellow businessperson in the area and TSh20,000 to pay people who helped him to slaughter and clean the cow's intestines. In this regard, he should have remained with TSh310,000. I then asked a question, which bothered him: 'Did you count your money after selling?' He answered: 'I did not count my money, but I know how much I sold'.

Operating within the modern discourse of business principles that informed their entrepreneurship training and assessment component of my study, I attempted to explain to him that money could not just disappear, which means that he probably made only TSh80,000, otherwise the money was stolen or dropped somewhere. At this point he could not take it anymore and strongly exclaimed: 'Nimeibiwa kwa dawa, wamenichezea mchezo' (medicine has been used to steal from me, they have played a game on me). A month before, his friend claimed that he had also lost some money in a mysterious way. He told him that the slaughterhouse was full of witchcraft practices. Following the pattern of circulation of popular discourses on chuma ulete, the young man retold the account to me in affirmation: '[My friend] said there is witchcraft on money. The money you see is not money. There are people who play the witchcraft game by buying things with money even though it is not money, and there are those who give you money, but it is witchcraft that pulls all the money you earn to them'.

$\mathrm{He}$ called his friend and they agreed to meet immediately at the slaughterhouse as the friend had a cow to slaughter that evening. Once we got there, the adolescent narrated his account to his friend and, as soon as he finished, his friend said: 'These things exist, Don. Make a plan to go to a traditional healer so s/he can make dawa for you against chuma ulete. Otherwise you would be working for other people'. The man decided to follow his friend's advice by visiting a mtaalam in one of the most famous areas for witchcraft in Tanzania, namely Tanga. The expert gave him a TSh5,000 note that he was required to put in his wallet. It was 'magic money', as he recalls the words of the expert, 'with power to bring more money to his business'. He also recalls that the expert informed him that the magic only lasts for six months, after which he should come back to the expert to renew it. To get the magic money, the adolescent had to pay 
TSh200,000 to the mtaalam. Unfortunately, at that time he only had TSh100,000. Yet the expert allowed him to pay it as an advanced deposit and the remaining amount was to be paid via mobile money before he started his business in order for the 'magic money' to work.

The adolescent's account and encounter underscore the centrality of both technology and orality in the circulation of the popular discourses on chuma ulete. It is by word of mouth, aided by mobile communication, that he triangulated his account and encounter with that of his friend. It is also through modern technological services that he partly paid the mtaalam for the dawa of chuma ulete, highlighting the connection between the occult economy and technology that Geschiere (1997) underscores in relation to the argument of Comaroff and Comaroff (1999) about the role of neoliberalism in attenuating such economies. Both the cases of female and male adolescents above indicate that, in suspecting or believing that certain forms of currency are tied to witchcraft, young entrepreneurs in-the-making are operating as rational economic subjects who are capable of distinguishing different 'forms' of currency. They are also able to evaluate these forms differently, even if these evaluations seem to contradict the rational principles of business that they were taught. In this sense, their conception of the value of money and the choices they make about accepting or rejecting the exchange of value or commodity are mediated by beliefs and popular discourses on such beliefs.

Other adolescents, from Abrahamic religions, however, protect themselves through religious prayers. As I have noted earlier, most of the youths in my study did not physically or personally encounter witches or witchcraft. However, due to their knowledge of popular discourses, most of them feared that experiencing such encounters are real. Hence some opted to protect themselves and/or their businesses. Here it is important to recall that, although all the adolescents who participated in my study believed that there was some association between witchcraft and businesses, only six stated that they have observed or witnessed someone or themselves being bewitched. This means that what is important, is the fact that a belief in the association between witchcraft and businesses is ubiquitous. It appears that the training that these entrepreneurs received from formal institutions that have made it their responsibility to prepare them to be successful entrepreneurs, did not provide them with a conceptual framework on how the capitalist system rewards efforts unevenly. In some respects, this is also true, when alluding to 
the address of President Reagan to the World Bank, namely a belief in the magic of the invisible hand of the market.

In the case of Islam, I found that some adolescents are using texts from the Qur'an, amulets, and charms to protect their businesses. For instance, when I was looking for change to give one of an adolescent's customers who had handed me a TSh2,000 note (when the adolescent had walked out for a moment), I spotted a page from the Qur'an under a rag where he kept loose coins. The adolescent later told me that it was to protect him from human envy and majini (djinns). He had learnt about the protection through his brother who organized for a Sheikh to perform an Islamic ritual and $d u a$ (prayer) for his business. Although he did not specifically invoke the term 'chuma ulete', his account on how his business mysteriously went bad and left him poor, draws from the same discourse. In trying to find an explanation for his misfortune, he encountered a mtaalam who told him that a jini (djinn) possessed him when he was traveling in an area that is regarded as having high incidents of witchcraft. The jini apparently did not like the type of business he was conducting except that of selling charcoal. It was then that his brother directed him to the Islamic cleric. The adolescent also bathed in dawa and received chale (body piercing) associated with the African Traditional Religions (ATR) from his grandmother. However, as Topan (2009:60) relates in regard to these two forms of religion, 'one can say that spirit possession has been modified or adapted to a degree that makes it "practisable" by ordinary Muslims without a feeling of serious discomfort about its "incompatibility" or "incongruity" with Islam'. It is in this domestication or syncretic regard that a strong Muslim like this adolescent could practice both.

In the case of Christianity, the adolescents use prayers and holy water, among other things, for protection from witchcraft. For instance, the mother of one of the adolescents who had become a Pentecostal after being diagnosed with a terminal illness, organized a prayer meeting as soon as her daughter received a business grant. She also encouraged her to fast and pray as a way to ask blessings for the new venture. They both prayed and fasted for three days. When I asked if she believed the prayer will protect the shop, her answer was very elaborate: 'First, I do believe in God and that there are evil powers. Second, even though I know my shop has not been attacked by witches, there are a lot of people who are not happy with the fact that I am a young person running a shop. So, they can wish harm on me. Third, prayers 
are a general protection for many things. Therefore, they were praying for me to have success. Lastly, witchcraft exists, so, such prayers can help to protect things in the future if it happens'. It is interesting to note that paying one's tithe and offerings are also conceived as ways in which God blesses a business.

Lindhardt (2009:50) aptly captures the connection between such religious rituals and the neoliberal market economy:

Hence money in its most concrete and material form becomes the site of convergence between market economies and spiritual blessings. Second, as previously explained, money that circulates in city markets, where different kinds of occult powers are working, might disappear from pockets and purses. Praying over money makes it immune to such mysterious disappearances.

The explanatory power of the occult economy in showing how such religious beliefs are intimately connected to neoliberalism cannot be overemphasized. 'In this historical era', White (2013:141) reiterates, 'all our relations are framed one or another way by the circulation of capital through human interactions' in forms like money, work, and debt, which are 'social forms as much as economic ones', although they 'might appear at first to have very little to do with what we would in a formal sense call economic life'. What this scholar terms the 'conditioning stuff of relationship', shapes our social ties that are also subject to the rhythm of capital in the neoliberal era. In doing so, it also permeates the intimate relations that people have with what they regard as spiritual beings and supernatural powers impacting their lives.

What clearly emerges from these accounts and encounters is that money is central in the mediation of the visible and invisible. In line with this, White (2013:144) notes in the case of a young man who had 'no steady and reliable stream of money' but consulted a diviner for a ritual regarding an invisible ancestor: 'Money is a prerequisite for the motion of all kinds of value from point to point in the larger interpersonal network of interests and solidarities that incorporates both visible beings and spirits'. Although 'the absence of money', as he further notes, 'stalls the same circulation, or brings it into a state of unreliable stops and starts' (White 2013:144), the case of one of the adolescents in my study above indicates that even when one does not have the full amount demanded, what is available can still be accepted. This, 
in itself, is an indication that the expertise on mediation between the visible and invisible, at least in the neoliberal context, is primarily a business. White (2013:144), following Ashforth (2011), relates it as follows:

Another way of putting this is to say that the absence of money blocks the flow of value from act to act in time, implying that actions are linked to one another here through the mediation of monetary equivalences. In other words, by paying close attention in a realist way to the practices that organize transactions with the invisible realm, we find ourselves immediately in a scene that is defined by its economic constitution.

However, it is such use of money to generate money that makes critics of chuma ulete view it as a sham. Nevertheless, for those who believe that they encountered it negatively, the struggle against it is real, while those who seem to encounter it positively, celebrate its apparent efficacy.

\section{Conclusion}

In this article, I have attempted to show how the popular discourses of chuma ulete as a form of witchcraft centered on stealing money through magic, circulates and informs choices that young people make in relation to business and money. By using the case business studies, a public discourse on entrepreneurship, and a study on young entrepreneurs, I have also shown how such choices are mediated through beliefs on the existence or inexistence of witchcraft. As such, two diametrically opposed sets of approaches emerge, respectively in dealing with chuma ulete: One centers around seeking traditional healing and religious means to curb it, while the other is based on using rational business principles of accounting and record keeping. I have, however, not put a normative value on these approaches in this article. I have rather unpacked how each approach has its own form of rationality centered on the utility of money in the context of the precariousness that neoliberalism has caused in Tanzania.

The era of neoliberalism was embarked upon in earnest after the retirement of the first president of independent Tanzania, Mwalimu Julius Nyerere in 1985, two years after the address to the annual meeting of the 
World Bank in 1983 by President Reagan. As quoted earlier, he declared that, for nations and even individuals to succeed in business, they have to place 'their belief in the magic of the marketplace'. From 1985 onwards, in the wake of the retirement from the presidency of the socialist inclined Nyerere, Tanzania embraced the neoliberal economic agenda with gusto. The state withdrew from providing support to citizens in terms of basic provisions, such as education and health, as well as permitting the capitalist market forces to operate on a long leash from state regulation and control. Suddenly, citizens - most of them being brought up in a command economy where rewards from factors of production, namely land, labor, capital, and entrepreneurship, are predictably regulated by state planning mechanisms - found themselves at the deep end of the neoliberal market pool. In this environment, rewards from factors of production in dependent neoliberal economies like those of postsocialist Tanzania are often unpredictable and even miraculous. No wonder that this is the period that saw the emergence of popular discourses on witchcraft in business undertakings that are vividly encapsulated in chuma ulete that has become so popular to the extent that there is a song named after it and ongoing debates about it in the public space.

One cannot overemphasize that there is an urgent need for further research on the interface between discourses on witchcraft in business and personal narratives of success and failure by young entrepreneurs. Findings from such research would better determine how entrepreneurship training programs, offered to adolescents, may be better able to psychologically prepare them for what they invariably have to encounter in the marketplace of a dependent neoliberal economy such as that of postsocialist Tanzania. That would also enable anthropologists to locate emerging discourses, such as that of chuma ulete, within the broader and longer history of the gendered, classed, and ageist witchcraft discourses in Africa in general, and Tanzania in particular.

\section{References}

African Gospel. 2017. Uchawi noma: Angalia alichofanyiwa mwizi. YouTube. Available at: https://www.youtube.com/watch?v=BDaPsbg FfLU. (Accessed on May 26, 2020.) 
Chuma Ulete: Business and Discourses of Witchcraft in Neoliberal Tanzania

Ashforth, A. 2005. Witchcraft, violence, and democracy in South Africa. Chicago: University of Chicago Press.

Ashforth, A. 2011. AIDS, religious enthusiasm and spiritual insecurity in Africa. Global Public Health 6, suppl. 2:132-147.

Bongmba, E.K. 2001. African witchcraft and otherness: A philosophical and theological critique of intersubjective relations. Albany: State University of New York Press.

Bryceson, D.F., J.B. Jønsson \& R. Sherrington 2010. Miners' magic: Artisanal mining, the albino fetish and murder in Tanzania. The Journal of Modern African Studies 48, 3: 353-382.

Chachage, S.L. \& M.J. Mbilinyi (eds.) 2003. Against Neoliberalism: Gender, democracy, and development. Dar es Salaam: E\&D Vision Publishing.

Comaroff, J. \& J.L. Comaroff 1999. Occult economies and the violence of abstraction: Notes from the South African postcolony. American Ethnologist 26, 2: 279-303.

Crick, M. 1976. Explorations in language and meaning: Towards a semantic anthropology. London: Malaby Press.

Englund, H. 1996. Witchcraft, modernity and the person: The morality of accumulation in central Malawi. Critique of Anthropology 16, 3: 257279.

Evans-Pritchard, E.E. 1978. Hexerei, Orakel und Magie bei den Zande. Frankfurt: Suhrkamp.

Evans-Pritchard, E.E. 1937. Witchcraft, oracles and magic among the Azande. Vol. 12. London: Oxford University Press.

Fortes, M. 1953. The structure of unilineal descent groups. American Anthropologist 55, 1: 17-41.

Foucault, P.-M. 1972. The archaeology of knowledge and the discourse on language. New York: Pantheon.

Foucault, P.-M. 1979. Discipline and punish: The birth of the prison. New York: Vintage Books.

Foucault, P.-M. 1982. The subject and power. Critical Inquiry 8, 4: 777-795.

Gaskill, M. 2010. Witchcraft: A very short introduction. Oxford: Oxford University Press.

Geschiere, P. 1997. The modernity of witchcraft: Politics and the occult in postcolonial Africa. Charlottesville VA: University of Virginia Press.

Geschiere, P. 2006. Witchcraft and modernity: Thoughts about a strange complicity. In Kiernan, J. (ed.): The power of the occult in modern 
Africa: Continuity and innovation in the renewal of African cosmologies. Berlin: Lit Verlag.

Gluckman, M. 1944. The logic of African science and witchcraft: An appreciation of Evans-Pritchard's 'witchcraft, oracles and magic among the Azande' of the Sudan. Indianapolis: Bobbs-Merrill.

Green, M. 2015. Ask a mind: Is studying witchcraft 'useful' for development? Savage minds: Notes and queries in anthropology. Available at: https://savageminds.org/2015/06/07/ask-a-mind-is-studying-witchcraftuseful-for-development. (Accessed on January 8, 2019.)

Green, M., \& S. Mesaki 2005. The birth of the 'salon': Poverty, 'modernization', and dealing with witchcraft in southern Tanzania. American Ethnologist 32, 3: 371-388.

Horton, R. 1967. African traditional thought and Western science. Africa: Journal of the International African Institute 37, 2: 155-187.

K24 TV. 2018. Mwizi wa samaki aina ya dagaa, avamiwa na nyuki, Kisii. YouTube. Available at: https://www.youtube.com/watch?v=ld3h5nZy7o. (Accessed on May 26, 2020.)

Kohnert, D. 2002. Occult beliefs, globalisation and the quest for development in African societies: The example of South Africa. In Mitchell, G. \& E. Mullen (eds.): Religion and the political imagination in a changing South Africa. New York: Waxman. URL: https://www.researchgate. net/publication/261723087 Occult beliefs globalization and the que st for development in African societies the example of South Afr ica. (Accessed on January 6, 2019).

Lewis, I.M. 1997. The Shaman's quest in Africa (`̀ la recherche d'un Chamanisme Africain). Cahiers d'études Africaines 37, 145: 119-135.

Lindhardt, M. 2009. More than just money: The faith gospel and occult economies in contemporary Tanzania. The Journal of Alternative and Emergent Religions 13, 1: 41-67.

Lindhardt, M. 2016. Miracle makers and money takers: Healers, prosperity preachers and fraud in contemporary Tanzania. In Van Eck, A. (ed.): In good faith: Minority religions and fraud. Aldershot: Ashgate.

Malefakis, A. 2018. Gridlocked in the city: Kinship and witchcraft among Wayao street vendors in Dar Es Salaam, Tanzania. Africa 88, 1: 51-71.

McCaskie, T.C. 2008. Akwantemfi - 'In mid-journey': An Asante shrine today and its clients. Journal of Religion in Africa 38, 1: 1-24. 
Mesaki, S. 1993. Witchcraft and witch-killings in Tanzania: Paradox and dilemma. PhD thesis, Department of Sociology and Anthropology, University of Dar es Salaam, Tanzania.

Mesaki, S. 1995. The evolution and essence of witchcraft in pre-colonial African societies. Transafrican Journal of History 24: 162-177.

Meyer, B. 1995. Delivered from the powers of darkness: Confessions of satanic riches in Christian Ghana. Africa 65, 2: 236-255.

Mgumia, J.H. 2017. Choices on money: Entrepreneurship and youth aspirations in Tanzania. PhD thesis, Department of Anthropology, University of the Witwatersrand, Johannesburg.

Mgumia, J.H. [2020]. Chuma Ulete as a popularized witchcraft discourse in small businesses. Tanzania Journal of Sociology (forthcoming).

Ministry of Trade and Industry. 2012. National baseline survey report: Micro, small, and medium enterprises in Tanzania. Dar es Salaam: Financial Sector Deepening Trust.

Mohab TV Online. 2018. Uchawi: Mwizi wa Bufa Ashambuliwa na Nyuki. YouTube. Available at: https://www.youtube.com/watch?v=6zwd7Y Oh-Eg. (Accessed on May 26, 2020.)

Moore, H.L. \& T. Sanders (eds.) 2001. Magical interpretations, material realities: Modernity, witchcraft and the occult in postcolonial Africa. London: Routledge.

Msafiri, A.G. 2008. Globalization of concern. Vol. 1. Dar es Salaam: Dar es Salaam University Press.

Mwakyusa, R.S. 2017. Chuma Ulete. YouTube. Available at: https:// www.youtube.com/watch?v=JTqCnZU8atY. (Accessed on February 18, 2020.)

Niehaus, I.A., E. Mohala \& K. Shokane 2001. Witchcraft, power, and politics: Exploring the occult in the South African Lowveld. London: Pluto Press.

Olsen, W.C. 2002. Children for death: Money, wealth, and witchcraft suspicion in colonial Asante. Cahiers d'études Africaines 167, 3: 521550.

Reagan, R. 1983. Opening remarks by Ronald Reagan, president of the United States. In International Bank for Reconstruction and Development International Finance Corporation International Development Association: Summary proceedings: 1983 annual meetings of the boards of Governors. Washington D.C.: The World Bank. 
Richter, R., T. Flowers \& E.K. Bongmba 2017. Witchcraft as a social diagnosis: Traditional Ghanaian beliefs and global health. London: Lexington Books.

Sanders, T. 1999. Modernity, wealth, and witchcraft in Tanzania. Research in Economic Anthropology, 20: 117-134.

Sanders, T. 2001. Save our skins: Structural adjustment, morality and the occult in Tanzania. In Moore, H. \& T. Sanders (eds.): Magical interpretations, material realities: Modernity, witchcraft and the occult in postcolonial Africa. London: Routledge.

Sanders, T. 2003. Reconsidering witchcraft: Postcolonial Africa and analytic (un)certainties. American Anthropologist 105, 2: 338-352.

Senellart, M. \& P.-M. Foucault (eds.) 2008. The birth of biopolitics: Lectures at the Collège de France 1978-1979. Burchell, G. (trans.). New York: Palgrave Macmillan.

Sherrington, R. 2007. Mob justice, metaphysical punishment and the moralisation of accumulation in urban Tanzania. Cambridge Anthropology 27, 1: 1-24.

Shivji, I.G. 2006. Let the people speak: Tanzania down the road to neoliberalism. Dakar: CODESRIA.

Singleton, M. 1979. Dawa: Beyond science and superstition (Tanzania). Anthropos 5, 6: 817-863.

Topan, F. 2009. Towards a paradigm of Swahili religious knowledge: Some observations. In Larsen, K (ed.): Knowledge, renewal and religion: Repositioning and changing ideological and material circumstances among the Swahili on the east African coast. Uppsala: Nordiska Afrikainstitutet.

White, H. 2013. Materiality, form, and context: Marx contra Latour. Victorian Studies 55, 4: 667-682.

Dr Jacqueline Halima Mgumia Department of Sociology and Anthropology University of Dar es Salaam jhm11@albion.edu 